\title{
EFFECT OF TREVESIA PALMATA ON SOME BIOCHEMICAL AND HAEMATOLOGICAL PARAMETERS
}

\author{
Sharubam Victoria \\ Department of Pharmacy \\ RIPANS, Aizawl, Mizoram, India \\ Ngurzampuii Sailo \\ Department of Pharmacy \\ RIPANS, Aizawl, Mizoram, India
}

\author{
H. Lahlenmawia \\ Department of Pharmacy \\ RIPANS, Aizawl, Mizoram, India \\ Longjam Shantabi \\ Department of Physiology and Biochemistry \\ College of Veterinary Sciences and A.H, CAU \\ Selesih, Aizawl, Mizoram, India
}

\begin{abstract}
The acute toxic effects of different doses of methanolic leaf extract of Trevesia palmata (METP) was studied in rats. The oral administration of different doses of Trevesia palmata did not show any mortality upto $2000 \mathrm{mg} / \mathrm{kg}$ b.wt. orally in rats. Therefore, it was concluded that METP was found to be safe as such and did not have any toxic manifestations upto the dose of $2000 \mathrm{mg} / \mathrm{kg} \mathrm{b}$. wt. Hence 1/10th $(200 \mathrm{mg} / \mathrm{kg}$, po) and $1 / 5$ th $(400 \mathrm{mg} / \mathrm{kg}$, p.o $)$ of this dose were employed for further pharmacological investigations.

The methanol extract of Trevesia palmata was estimated for various biochemical and Haematological parameters. The administration of different doses of METP showed a significant decrease as compared to Control as indicated by lower activities of Serum Glutamic Oxaloacetic Transaminase (SGOT) or Aspartate Aminotransferase (AST) , Serum Glutamic Pyruvic Transaminase (SGPT) alkaline phosphatase (ALP) enzymes, total bilirubin, total Cholesterol and albumin, in rats along with the elevation of total proteins, content. Similarly, The results of the haematological parameters showed that the mean RBC and $\mathrm{Hb}$ concentrations increased significantly $(p<0.05)$ at $200 \mathrm{mg} / \mathrm{kg}$ and $400 \mathrm{mg} / \mathrm{kg}$ of administration. The eosinophil count was decreased significantly at $200 \mathrm{mg} / \mathrm{kg}$ and 400 $\mathrm{mg} / \mathrm{kg}$ of administration $(\mathbf{p}<\mathbf{0 . 0 5})$. Neutrophil and lymphocytes did not show significant difference at all doses of administration. There was no significant difference in $\mathrm{RBC}$, Hb concentrations as well as the eosinophil at $200 \mathrm{mg} / \mathrm{kg}$ and $400 \mathrm{mg} / \mathrm{kg}$ of administration. In this study, significant increases in $\mathrm{RBC}$, WBC, $\mathrm{Hb}$ at $200 \mathrm{mg} / \mathrm{kg}$ and $400 \mathrm{mg} / \mathrm{kg}$ were observed. This may be due to the presence of erythropoietin-like principals in the extract which probably stimulated erythropoietin synthesis or release at minimal doses $(200 \mathrm{mg} / \mathrm{kg}$ and $400 \mathrm{mg} / \mathrm{kg})$.
\end{abstract}

Keywords: Trevesia palmata, acute toxicity, biochemical,

\section{INTRODUCTION}

Herbal drugs play an important role in health related issue. Ancient Indian literature incorporates a remarkably broad definition of medicinal plants and considers 'all' plant parts to be potential sources of medicinal substances according to Shankar and Ved (2003). From Pareek (1996); Mukhopadhya (1996) as per WHO estimate, about $80 \%$ of the population in the developing countries depends mainly on plants or natural medicines for their health care needs

The plant Trevesia palmata (Araliaceae) is native to Asia, China, Bangladesh, Bhutan, India, Nepal, Cambodia, Laos, Myanmar, Thailand and Vietnam. They are evergreen tree to 15-20 feet tall with few or no side branches and topped with a crown of long stalked 1-2 foot wide leaves that are deeply lobed giving the leaf a lacy snow flake look. According to Matthew and Jebb. (1998), the genus name Trevesia was described by the Italian Botanist Roberto De Visiani in 1840. Rahman, Uddin and Wilcock (2007) mentioned that this species is used in traditional system of medicines to treat venereal diseases and to treat bruising. Its potential for lowering of blood glucose and alleviating pain with methanolic extract of Trevesia palmata is also been reported by Rahman et al. (2014). So far no proper biochemical and haematological studies have been reported for this plant, in view of this present study was undertaken to assess the biochemical and haematological effects of Trevesia palmata.

\section{MATERIALS AND METHODS}

\section{A. Plant material}

The methanolic extract of the leaves of Trevesia palmata (METP) were used for the present study.

B. Animals

The study was reviewed and approved by Institutional Animal Ethics Committee of RIPANS, Aizawl and was in accordance with the guidelines of the Committee 


\section{International Journal of Engineering Applied Sciences and Technology, 2019 \\ Vol. 4, Issue 3, ISSN No. 2455-2143, Pages 610-614 \\ Published Online July 2019 in IJEAST (http://www.ijeast.com)}

for the purpose of Control and Supervision of Experimental animals (CPCSEA) (Approval Nos. IAEC/RIPANS/17)

Healthy Wistar albino Rats were selected for acute toxicity studies. They were grouped and housed in polyacrylic- cages $(38 \times 23 \times 10 \mathrm{~cm})$, maintained under standard laboratory conditions $\left(25 \pm 2^{\circ} \mathrm{C}\right)$ with dark/light cycle (12/12hour). They were allowed free access to standard dry pellet diet and water ad libitum. The animals were acclimatized to laboratory conditions for 10 days before commencement of the experiment given by Ghosh (1984).

\section{Housing and feeding conditions}

Healthy young adult animals of commonly used laboratory strains should be employed. Females should be nulliparous and non pregnant. Each animal should be between 8 and 12 weeks old and its weight should fall in an interval within $\pm 20 \%$ of the mean weight. The temperature in the experimental animal room should be $22^{\circ} \mathrm{C}( \pm 3 \mathrm{C})$. Although the relative humidity should be at least $30 \%$ and preferably not exceed $70 \%$ other than during room cleaning the aim should be $50-60 \%$. Lighting should be artificial, the sequence being 12 hours light, 12 hours dark. For feeding, conventional laboratory diets may be used with an unlimited supply of drinking water.

\section{Administration of doses}

After overnight (18hr) fasting condition, the animals were weighed and the test substances (METP) was administered in a single dose by gavage using a stomach tube or a suitable intubation canula. In the unusual circumstances however a single dose would not be possible, the dose could be given in smaller fraction over a period not exceeding $24 \mathrm{hrs}$. After the test substance administration, food may be withheld for a further 3-4 hrs in rats or 1-2 hrs in mice.

\section{E. Toxicity study}

An acute toxicity study relating for the determination of $\mathrm{LD}_{50}$ was performed as per OECD-425 guidelines, Acute Oral Toxicity - up-and-down procedure OECD (2008). There are several variations of the up-and-down experimental design. The method is easiest to apply to materials that produce death within one to two days. The dose level to be used as the starting dose is selected from one of four fixed levels, 5, 50, 300 and $2000 \mathrm{mg} / \mathrm{kg}$ b.wt. The starting dose level should be that which is likely to produce mortality in some of the dosed animals.

When available information suggests that mortality is unexpected at the highest starting dose level $(2000 \mathrm{mg} / \mathrm{kg}$ b.wt.), then a limit test is conducted. When there is no information on a substance to be tested, for animal welfare reason it is recommended to use the starting dose of 300 $\mathrm{mg} / \mathrm{kg} \mathrm{b.wt}$.

In up-and-down procedure, first, this limit test is performed to identify the chemicals that are likely to have low toxicity. The limit test is a sequential test that uses a maximum of 6 animals. A test dose upto 2000 or exceptionally $5000 \mathrm{mg} / \mathrm{kg}$ may be used. If the chemical passes this test, then it can be inferred to be safe upto the administered dose. In case it fails the limit test, then it is to be taken from the main test, consisting of one of the other lower fixed dose levels. Dosing is stopped when an estimate of the LD50 is obtained and a confidence interval is calculated based on the status of all the animals at termination.

In the present investigation of the studied plant ie, Trevesia palmata its fruits are edible as vegetables; hence probability of the toxicity for their extracts is quite low. Therefore in acute toxicity study of the extracts, first the limit tests with 2000 $\mathrm{mg} / \mathrm{kg}$ b.wt were carried out directly.

Animals were observed individually after dosing at least once during the first 30 minutes, periodically during the first $24 \mathrm{hrs,}$ with special attention given during the first $4 \mathrm{hrs}$ and daily thereafter, for a total of 14 days, except where they need to be removed from the study and humanely killed for animal welfare reasons or are found death. However, the duration of observation should be determined by the toxic reactions, time of onset and length of recovery period and may thus be extended when considered necessary. According to Chan and Hayes (2008), the times at which signs of toxicity appear and disappear are important, especially if there is a tendency for toxic signs to be delayed. All observations were systematically recorded for each animal.

\section{$\boldsymbol{F}$. Estimation of biochemical parameters}

Reitman and Frankel (1957); Kind and King (1954) had mentioned that serum was analysed for various biochemical parameters like serum glutamic pyruvate transaminase (SGPT), serum glutamic oxaloacetic transaminase (SGOT) and alkaline phosphatase (ALP) activities. The total protein concentration and total bilirubin were also measured by using Lowry, Rosebrough and Far (1951). All the analysis was performed by using commercially available kits from Erba Mannheim.

\section{G. Haematological studies}

The effect of METP on peripheral blood was investigated. RBC and WBC counts were estimated using Neubauer haemocytometer and estimation of haemoglobin using Sahli's haemoglobinometer were carried out by standard procedures from the blood obtained intracardially by following the methods from D'Armour, Blood and Belden (1965); Wintrobe et al. (1961).

\section{RESULTS AND DISCUSSION}

\section{Acute toxicity studies}

From the present study, the methanolic extracts of Trevesia palmata at $2000 \mathrm{mg} / \mathrm{kg}$ passes the limit test and did not show mortality upto $2000 \mathrm{mg} / \mathrm{kg}$ b.wt. orally. Therefore, it was concluded that METP was found to be safe as such and did not have any toxic manifestations upto the dose of $2000 \mathrm{mg} / \mathrm{kg} \mathrm{b}$. wt. It can be considered as a nontoxic substance. Hence 1/10th 


\section{International Journal of Engineering Applied Sciences and Technology, 2019 \\ Vol. 4, Issue 3, ISSN No. 2455-2143, Pages 610-614 \\ Published Online July 2019 in IJEAST (http://www.ijeast.com)}

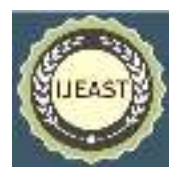

(200 mg/kg, po) and 1/5th (400 mg/kg, p.o) of this dose were employed for further pharmacological investigations.

\section{Biochemical Measurements}

Administration of $\mathrm{CCl}_{4}$ to the animals resulted in a marked elevation of serum transaminases (SGOT, SGPT), serum alkaline phosphatase (ALP) and total bilirubin (TB), when compared with those of normal control animals. However serum total protein level was decreased. The rats treated with $200 \mathrm{mg} / \mathrm{kg}$ and $400 \mathrm{mg} / \mathrm{kg}$ Trevesia palmata extracts and silymarin showed a significant decrease $(\mathrm{p}<0.001)$ in all the elevated serum marker levels SGOT, SGPT, ALP and TB and significant increase $(\mathrm{p}<0.001)$ in total protein concentration (Table-1, Fig.1) which showed the restoration of the level of liver function biochemistry to more or less normal values.

Cholesterol levels were increased significantly $(\mathrm{p}<0.05)$ in the $\mathrm{CCl}_{4}$ group compared with the control. There was significant $(\mathrm{p}<0.05)$ decreases in cholesterol levels treated with 200 and $400 \mathrm{mg} / \mathrm{kg}$. b. w. METP compared with the $\mathrm{CCl}_{4}$ treated rats.

The $\mathrm{CCl}_{4}$ treatment markedly affected the liver specific enzymes. It was found that a significant $(\mathrm{p}<0.05)$ increase in serum AST, ALT and ALP activities of $\mathrm{CCL}_{4}$ treated rats. This result suggests that these hepatic biomarkers were elevated in the serum due to release of the enzymes from damaged liver. However a significant $(p<0.05)$ was observed in the respective serum activities of rats given. A significant decrease $(\mathrm{p}<0.05)$ in serum Bilirubin, total proteins, and Albumin of $\mathrm{CCl}_{4}$ treated rats was observed. The enhanced levels of these serum marker enzymes observed in $\mathrm{CCl}_{4}$ treated rats in the present study correspond to the extensive liver damage induced by the toxin. Restoration of the levels of these enzymes towards near normal values in the METP at 200 and $400 \mathrm{mg} / \mathrm{kg}$ and silymarin treated animals is a clear manifestation of anti-hepatotoxic effect of the extract and the drug. Increase in serum bilirubin in $\mathrm{CCl}_{4}$ control group animals reflected the depth of jaundice, which was attenuated to the normal level in the extracts treated groups, indicating their hepatoprotective effect further. The lowered level of total protein recorded in the serum of $\mathrm{CCl}_{4}$ intoxicated rats reveals the severity of hepatopathy, while the attainment of near normalcy in total protein content of serum of the treated groups potentiates the hepatoprotective effects of the extract.

\section{Haematological studies}

The results of the haematological parameters showed that the mean $\mathrm{RBC}$ and $\mathrm{Hb}$ concentrations increased significantly $(\mathrm{p}<0.05)$ at $200 \mathrm{mg} / \mathrm{kg}$ and $400 \mathrm{mg} / \mathrm{kg}$ of administration. The eosinophil count was decreased significantly at $200 \mathrm{mg} / \mathrm{kg}$ and $400 \mathrm{mg} / \mathrm{kg}$ of administration $(\mathrm{p}<0.05)$. Neutrophil and lymphocytes did not show significant difference at all doses of administration. There was no significant difference in RBC, $\mathrm{Hb}$ concentrations as well as the eosinophil at $200 \mathrm{mg} / \mathrm{kg}$ and $400 \mathrm{mg} / \mathrm{kg}$ of administration (Table-2, Fig.2). Literature has shown that oral ingestion of medicinal compounds or drugs can alter the normal range of haematological parameters as cited from Ajagbonna, Onifade and Suleiman (1999); Ofuya and Ebong (1996). These alterations can either be positive or negative. In this study, significant increases in RBC, WBC, $\mathrm{Hb}$ at $200 \mathrm{mg} / \mathrm{kg}$ and $400 \mathrm{mg} / \mathrm{kg}$ were observed. This may be due to the presence of erythropoietin-like principals in the extract which probably stimulated erythropoietin synthesis or release at minimal doses $(200 \mathrm{mg} / \mathrm{kg}$ and $400 \mathrm{mg} / \mathrm{kg})$. According to Agbor and Odetola (2001), the active biological principles such as alkaloids, steroids, tannins, saponins and phenols contained in the extract, may be responsible for its hematopoietic effects. This results agrees with the findings of on the methanol leaf extract of Trevesia palmata.

The results showed that the extracts of Trevesia palmata caused increase in WBC count particularly with the doses of 200 and $400 \mathrm{mg} / \mathrm{kg}$. This finding suggests that the extract of Trevesia palmata plant probably contain agent(s) that stimulate (s) production of leucocytes. The presence of such agents had been shown in Trevesia palmata. The crucial role of WBC in defending the body against infection and tissue damage is well known. Thus the results of this study imply that Trevesia palmata are potent immune-stimulants and their use to treat immune-related diseases in herbal medicine can be justified. Additional evidence from this study suggests that the immune stimulant properties of these plants through their stimulatory effects on WBC production. In this respect, the observation that $200 \mathrm{mg} / \mathrm{kg}$ of Trevesia palmata caused increase in circulating neutrophils during differential count is important considering the fact that neutrophils are the main type of WBC that attack and destroy invading bacteria, viruses and other injurious agents.

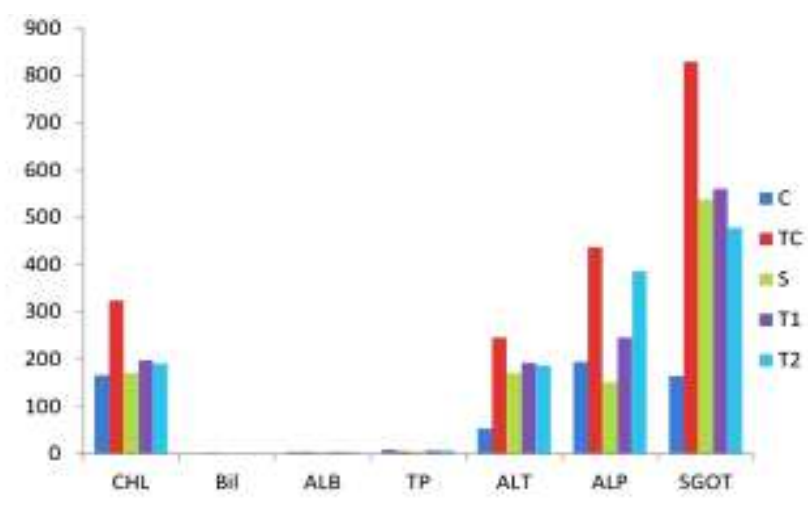

Fig.1. Effect of methanol extract of Trevesia palmata (METP) on serum enzyme levels, Total bilirubin and Total protein of $\mathrm{CCl} 4$ intoxicated rats 


\section{International Journal of Engineering Applied Sciences and Technology, 2019 \\ Vol. 4, Issue 3, ISSN No. 2455-2143, Pages 610-614 \\ Published Online July 2019 in IJEAST (http://www.ijeast.com)}

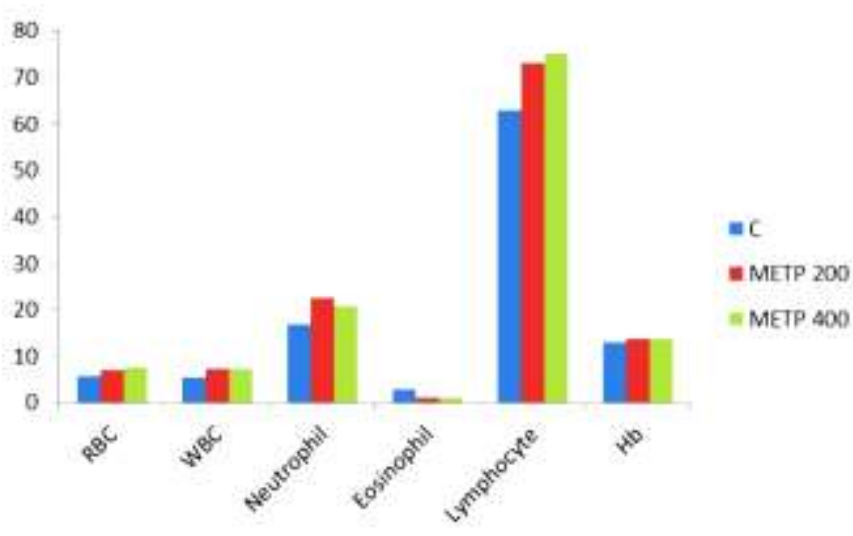

Fig. 2. Effects of methanol extracts of Trevesia palmata on Haematological examination

Table -1 Experiment Result

\begin{tabular}{|c|c|c|c|c|c|c|c|}
\hline Groups & $\begin{array}{l}\text { SGPT } \\
(\text { IU/L) }\end{array}$ & $\begin{array}{l}\text { SGPT } \\
\text { (IU/L) }\end{array}$ & $\begin{array}{c}\text { ALP } \\
\text { (IU/L) }\end{array}$ & $\begin{array}{c}\text { Total } \\
\text { bilirubin } \\
\text { (mg/dl) }\end{array}$ & $\begin{array}{c}\text { Total } \\
\text { protein } \\
(\mathrm{g} / \mathrm{dl})\end{array}$ & $\begin{array}{l}\text { Total } \\
\text { Choleste } \\
\text { rol (U/L) }\end{array}$ & $\begin{array}{c}\text { Serum } \\
\text { Album } \\
\text { in } \\
(\mathrm{mg} / \mathrm{dl})\end{array}$ \\
\hline $\begin{array}{l}\text { Normal } \\
\text { Control }\end{array}$ & $\begin{array}{c}53.70 \pm \\
0.25\end{array}$ & $\begin{array}{c}164.73 \pm \\
0.48\end{array}$ & $\begin{array}{l}194.50 \\
\pm 0.80\end{array}$ & $\begin{array}{c}0.83 \pm \\
0.04\end{array}$ & $\begin{array}{l}8.95 \pm \\
0.004\end{array}$ & $\begin{array}{c}166.5 \pm \\
0.64\end{array}$ & $\begin{array}{l}4.11 \pm \\
0.004\end{array}$ \\
\hline $\begin{array}{c}\mathrm{CCL}_{4} \\
\text { control(1 } \\
\mathrm{m} \mathrm{l/kg} \\
\text { i.p.) }\end{array}$ & $\begin{array}{c}245.78 \\
\pm \\
0.29\end{array}$ & $\begin{array}{l}829 \pm \\
0.80\end{array}$ & $\begin{array}{l}437.12 \\
\pm 0.95\end{array}$ & $\begin{array}{l}2.66 \pm \\
0.06\end{array}$ & $\begin{array}{l}5.61 \pm \\
0.004\end{array}$ & $\begin{array}{c}324.25 \pm \\
0.48\end{array}$ & $\begin{array}{l}3.76 \pm \\
0.004\end{array}$ \\
\hline $\begin{array}{c}\text { Silymari } \\
\mathrm{n} \\
100 \mathrm{mg} / \mathrm{kg}\end{array}$ & $\begin{array}{c}171.71 \\
\pm \\
0.48^{* *}\end{array}$ & $\begin{array}{l}539.21 \pm \\
0.43^{* *}\end{array}$ & $\begin{array}{l}152.05 \\
\pm 0.60\end{array}$ & $\begin{array}{l}1.43 \pm \\
0.04\end{array}$ & $\begin{array}{l}5.72 \pm \\
0.47\end{array}$ & $\begin{array}{c}171.25 \pm \\
0.48\end{array}$ & $\begin{array}{l}4.12 \pm \\
0.007\end{array}$ \\
\hline $\begin{array}{c}\text { METP } \\
200 \mathrm{mg} / \mathrm{kg}\end{array}$ & $\begin{array}{c}192.36 \\
\pm \\
0.81\end{array}$ & $\begin{array}{c}560.46 \pm \\
0.61\end{array}$ & $\begin{array}{l}245.74 \\
\pm 0.74\end{array}$ & $\begin{array}{l}1.24 \pm \\
0.03\end{array}$ & $\begin{array}{l}7.19 \pm \\
0.59\end{array}$ & $\begin{array}{l}198 \pm \\
0.41\end{array}$ & $\begin{array}{l}4.02 \pm \\
0.007\end{array}$ \\
\hline $\begin{array}{c}\text { METP } \\
\text { 400mg/kg }\end{array}$ & $\begin{array}{l}186.89 \\
\pm 0.92\end{array}$ & $\begin{array}{c}478.25 \pm 0 \\
.59\end{array}$ & $\begin{array}{c}386.99 \\
\pm 0.73\end{array}$ & $\begin{array}{l}1.19 \pm \\
0.03\end{array}$ & $\begin{array}{c}7.22 \pm 0 . \\
55\end{array}$ & $91 \pm 0.41$ & $\begin{array}{l}13.83 \pm \\
0.006\end{array}$ \\
\hline
\end{tabular}

Values are Mean \pm S.E.M.; $\mathrm{n}=4$ in each group. $\mathrm{P}<0.001$; where the significance was performed by One way ANOVA followed by Dunnett's test.

Table 1 show the Effect of methanol extract of Trevesia palmata (METP) on serum enzyme levels, Total bilirubin and Total protein of $\mathrm{CCl}_{4}$ intoxicated rats.

Table -2 Experiment Result

\begin{tabular}{|c|c|c|c|}
\hline Parameters & Control & $\begin{array}{c}\text { METP }(200 \\
\mathrm{mg} / \mathrm{kg})\end{array}$ & $\begin{array}{c}\text { METP } \\
(400 \mathrm{mg} / \mathrm{kg})\end{array}$ \\
\hline RBC $\left(\mathbf{1 0}^{\mathbf{6}} \boldsymbol{\mu l}\right)$ & $\mathbf{5 . 8 4} \pm \mathbf{0 . 2 2}$ & $\mathbf{7 . 1 5} \pm \mathbf{0 . 2 7}$ & $\mathbf{7 . 6 5} \pm \mathbf{0 . 0 6}$ \\
\hline WBC & $\mathbf{5 . 3 7} \pm \mathbf{0 . 5 7}$ & $\mathbf{7 . 2 5} \pm \mathbf{0 . 3 7}$ & $\mathbf{7 . 2 7} \pm \mathbf{0 . 5 7}$ \\
\hline Neutrophil & $\mathbf{1 7} \pm \mathbf{6 . 2 0}$ & $\mathbf{2 2 . 7} \pm \mathbf{0 . 5 7}$ & $\mathbf{2 0 . 8} \pm \mathbf{1 . 2 0}$ \\
\hline Eosinophils & $\mathbf{3 . 0 0} \pm \mathbf{0 . 9 4}$ & $\mathbf{1 . 0 0} \pm \mathbf{0 . 6 3}$ & $\mathbf{1 . 2 0} \pm \mathbf{0 . 4 9}$ \\
\hline Lymphocytes & $\mathbf{6 3} \pm \mathbf{0 . 2 5}$ & $\mathbf{7 3} \pm \mathbf{0 . 6 3}$ & $\mathbf{7 5} \pm \mathbf{0 . 2 1}$ \\
\hline Hb $(\mathbf{G} / \mathbf{d l})$ & $\mathbf{1 2 . 9} \pm \mathbf{0 . 3 1}$ & $\mathbf{1 3 . 7} \pm \mathbf{0 . 4 0}$ & $\mathbf{1 3 . 7 7} \pm \mathbf{0 . 3 3}$ \\
\hline
\end{tabular}

RBC - red blood cells, WBC- white blood cells, Hbhaemoglobin; represents significant difference at $\mathrm{P}<0.05$.
Table 2 show the Effects of 9 days of oral administration of Trevesia palmata on Haematological examination.

\section{CONCLUSION}

From the present study we can conclude that the haematological findings reveals the extracts potency to maintain $\mathrm{RBC}, \mathrm{Hb}$ and $\mathrm{WBC}$ levels of blood which authenticate its immune stimulant properties and thus can be effective for immune related disorders. The methanolic extracts of Trevesia palmata has shown the ability to maintain the normal functions of liver. Extract effectively control the SGOT, SGPT, ALP, total cholesterol, total protein, total bilirubin and serum albumin levels in this study. Therefore, the study scientifically supports the usage of this plant in traditional medicine for treatment of liver disorders.

\section{ACKNOWLEDGEMENT}

The authors are thankful to the Department of Pharmacy, Regional Institute of Paramedical and Nursing Sciences, Aizawl, Mizoram for providing facilities for carrying out this work.

\section{REFERENCE}

[1] Shankar D., Ved D.K. (2003), "Indian Forester," Vol. 129, (pp.275-288).

[2] Pareek S.K.(1996), "Medicinal Plants in India: Present Status and Future Prospects. Prospects of Medicinal Plants; Gautam P L (et al)" Indian Society for Plant genetic resources, NBPGR campus: New Delhi, (pp.514).

[3] Mukhopadhyay S. (1996) "Conservation, Protection and Biodiversity of Medicinal Plants; Gautam P L (et al)," Ed.; Indian Society for Plant genetic resources, NBPGR campus: New Delhi; (pp.15-28).

[4] Matthew H.P., and Jebb. (1998) "A revision of the genus Trevesia (Araliaceae)," Glasra. Vol. 3, (pp.85-114).

[5] Rahman M.A., Uddin S.B. and Wilcock C.C. (2007) "Medicinal plants used by Chakma tribe in hill tracts districts of Bangladesh," Ind. J. Trad. Know. Vol. 6, (pp.518-517).

[6] Rahman K.M.H., Nandi J.K., Sultana S., Rahman S., Hossan S., Rahmatullah M. (2014), "Phytochemical screening, Anti hyperglycaemic and analgesic activity studies with methanol extracts of Trevesia palmata leaves," World J. Pharm. \&Pharm. Sci. Vol. 3, (pp.91101).

[7] Ghosh M.N. (1984) "Fundamentals of Experiment Pharmacology," 2nd Edition, Scientific Book Agency, Calcutta, (pp. 192-19).

[8] OECD. (2008) "Test Guideline 425, Acute Oral Toxicity - Up-and-Down Procedure". 


\section{International Journal of Engineering Applied Sciences and Technology, 2019 \\ Vol. 4, Issue 3, ISSN No. 2455-2143, Pages 610-614 \\ Published Online July 2019 in IJEAST (http://www.ijeast.com)}

[9] Chan P.K. and Hayes A.W. (1994) "Principle and Methods of Toxicology," 3rd edition, New York: Raven Press. 8.

[10] Reitman S., Frankel A.S. (1957) "A colorimetric method for the determination of serum glutamic oxaloacetic acid and glutamic pyruvic transaminase," Am. J. Clin. Path. Vol. 28, (pp. 53-56).

[11] Kind P.R.N. and King E.J. (1954) "Estimation of plasma phosphatase by determination of hydrolysed phenol with antipyrin,” J. Clin.Pathol. Vol. 7, (pp.322-331).

[12] Lowry O.H., Rosebrough N.J. and Far A.L. (1951) "Protein measurement with Folin Phenol reagent," J. Biol. Chem. Vol. 193, (pp.265- 275)

[13] D'Armour F.E., Blood F.R. and Belden D.A. (1965) "The manual for laboratory work in mammalian physiology," 3rd edition, The university of Chicago press, Illinois Chicago, (pp. 4-6).

[14] Wintrobe M.M., Lee G.R., Boggs D.R., Bithel T.C., Athens J.W., Foerester J. (1961) “Clinical Haematology," 5th edition, Les and Febiger, Philadelphia, (pp. 326).

[15] Ajagbonna O.P., Onifade K.I., Suleiman U. (1999) "Hematological and Biochemical changes in rats given extract of Calotropis procera," Sakoto J. veterinary Sci. Vol.1, (pp.36-42).

[16] Ofuya Z.M. and Ebong O.O. (1996) "Plasma ascorbic acid levels in adult females in Port-Harcourt, SouthEastern Nigeria," West African J.Pharmacol. and Drug Res, Vol. 12, (pp.32-36).

[17] Agbor A.G. and Odetola A. A. (2001) "Hematological studies of Parquetina nigrescens on haemorrhagic anaemic rats," African J.Med. and Med. Sci. Vol.30, (pp.105-109). 